\title{
Synthesis and Characterization of New Tetraaza Macrocycles Bearing Two or Four $N$-Methoxyethyl Pendant Arms and Their Copper(II) and/or Nickel(II) Complexes
}

\author{
Shin-Geol Kang, Hyunja Kim, and Chee-Hun Kwak ${ }^{\dagger}, *$ \\ Department of Chemistry, Daegu University, Gyeongsan 712-714, Korea.*E-mail: sgkang@daegu.ac.kr \\ †Department of Chemistry, Sunchon National University, Sunchon 540-742, Korea. *E-mail: chkwak@sunchon.ac.kr \\ Received May 26, 2010, Accepted July 22, 2010
}

Key Words: Macrocycle, Copper(II) complex, Nickel(II) complex, Crystal structure, Methoxyethyl pendant arm

A variety of work has been concerned with the preparation of polyaza macrocyclic ligands and complexes bearing additional functional pendant arms because of their interesting chemical properties and potential applications. ${ }^{1-13}$ In general, coordination geometry and chemical properties of such compounds are strongly influenced by the nature and number of the functional groups.

Some polyaza macrocyclic complexes bearing pendant ether $\operatorname{group}(\mathrm{s})$, such as $\left[\mathrm{CuL}^{4}\right]^{2+},\left[\mathrm{NiL}^{5}\right]^{2+}$, and $\left[\mathrm{NiL}^{10}\right]^{2+}$, have been prepared and investigated. ${ }^{10-13}$ The preparation of $\left[\mathrm{CuL}^{4}\right]^{2+}$ and $\left[\mathrm{NiL}^{5}\right]^{2+}$ bearing two and one $\mathrm{N}-\mathrm{CH}_{2} \mathrm{OCH}_{3}$ groups, respectively, has been achieved by the reaction of $\mathrm{L}^{11}$ with methanol in the presence of the corresponding metal ion. ${ }^{10-11}$ It has been revealed that one of the two $\mathrm{N}-\mathrm{CH}_{2} \mathrm{OCH}_{3}$ groups in $\left[\mathrm{CuL}^{4}\right]^{2+}$ is coordinated to the metal ion, ${ }^{10}$ whereas the pendant arm of $\left[\mathrm{NiL}^{5}\right]^{2+}$ or $\left[\mathrm{NiL}^{10}\right]^{2+}$ is not involved in coordination. ${ }^{11,12}$ To our knowledge, they are rare examples of polyaza macrocyclic complexes bearing $\mathrm{N}-\left(\mathrm{CH}_{2}\right)_{\mathrm{n}} \mathrm{OCH}_{3}$ group(s). Furthermore, the isolation of the metal-free macrocycle $\mathrm{L}^{4}, \mathrm{~L}^{5}$, or $\mathrm{L}^{10}$ could not be achieved; ${ }^{10-12}$ both $\mathrm{L}^{4}$ and $\mathrm{L}^{5}$ are decomposed to $\mathrm{L}^{2}$ if they are removed from the coordination sphere. For this reason, chemical properties of polyaza macrocycles bearing $\mathrm{N}-\mathrm{CH}_{2} \mathrm{OCH}_{3}$ group(s) have not been intensively investigated. This prompted us to prepare various types of polyaza macrocycles bearing $\mathrm{N}-\left(\mathrm{CH}_{2}\right)_{\mathrm{n}} \mathrm{OCH}_{3}$ group(s) and their transition metal complexes.

In this work, we prepared $\mathrm{L}^{2}$ and $\mathrm{L}^{3}$ bearing two or four $N-\left(\mathrm{CH}_{2}\right)_{2} \mathrm{OCH}_{3}$ groups from the reaction of $\mathrm{L}^{1}$ with 1-bromo-2-methoxyethane. Their copper(II) and/or nickel(II) complexes were also prepared. Herein, we report the preparation and coordination behaviors of $\mathrm{L}^{2}$ and $\mathrm{L}^{3}$, along with the crystal structure of $\left[\mathrm{CuL}^{2}\right]\left(\mathrm{ClO}_{4}\right)_{2}$.

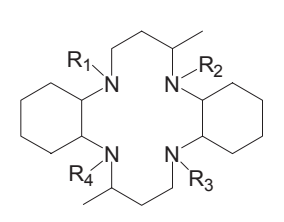

$\mathrm{L}^{1}: \mathrm{R}_{1}=\mathrm{R}_{2}=\mathrm{R}_{3}=\mathrm{R}_{4}=\mathrm{H}$

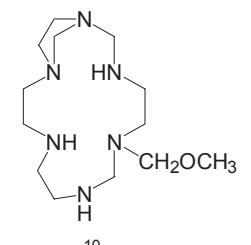

$\mathrm{L}^{10}$

$\mathrm{L}^{2}: \mathrm{R}_{1}=\mathrm{R}_{3}=\mathrm{CH}_{2} \mathrm{CH}_{2} \mathrm{OCH}_{3} ; \mathrm{R}_{2}=\mathrm{R}_{4}=\mathrm{H}$

$\mathrm{L}^{3}: \mathrm{R}_{1}=\mathrm{R}_{2}=\mathrm{R}_{3}=\mathrm{R}_{4}=\mathrm{CH}_{2} \mathrm{CH}_{2} \mathrm{OCH}_{3}$

$\mathrm{L}^{4}: \mathrm{R}_{1}=\mathrm{R}_{2}=\mathrm{CH}_{2} \mathrm{OCH}_{3} ; \mathrm{R}_{3}=\mathrm{R}_{4}=\mathrm{H}$

$\mathrm{L}^{5}: \mathrm{R}_{1}=\mathrm{CH}_{2} \mathrm{OCH}_{3} ; \mathrm{R}_{2}=\mathrm{R}_{3}=\mathrm{R}_{4}=\mathrm{H}$

$\mathrm{L}^{6}: \mathrm{R}_{1}=\mathrm{R}_{3}=\mathrm{CH}_{2} \mathrm{CH}_{2} \mathrm{OH} ; \mathrm{R}_{2}=\mathrm{R}_{4}=\mathrm{H}$

$\mathrm{L}^{7}: \mathrm{R}_{1}=\mathrm{R}_{2}=\mathrm{R}_{3}=\mathrm{R}_{4}=\mathrm{CH}_{2} \mathrm{CH}_{2} \mathrm{CH}_{3}$

$L^{8}: R_{1}=R_{3}=\mathrm{CH}_{2} \mathrm{CH}_{2} \mathrm{CN} ; \mathrm{R}_{2}=\mathrm{R}_{4}=\mathrm{H}$

$\mathrm{L}^{9}: \mathrm{R}_{1}=\mathrm{R}_{3}=\mathrm{CH}_{2} \mathrm{CH}_{2} \mathrm{CH}_{3} ; \mathrm{R}_{2}=\mathrm{R}_{4}=\mathrm{H}$

\section{Experimental Section}

Measurements. Infrared spectra were recorded with a Genesis II FT-IR spectrometer, electronic absorption spectra with an Analytic Jena Specord 200 UV-vis spectrophotometer, NMR spectra with a Varian Mercury 300 FT NMR spectrometer, and GC-mass spectra with a Shimadzu GCMSD-QP5050 spectrometer. Conductance measurements were taken with a Metrohm Herisau Conductometer E518. Magnetic moments were calculated from magnetic susceptibility data obtained at $293 \mathrm{~K}$ using a Johnson Matthey MK-1 magnetic susceptibility balance. FAB-mass spectra were performed at the Korea Basic Science Institute, Daegu, Korea. Elemental analyses were performed at the Research Center for Instrumental Analysis, Daegu University, Gyeongsan, Korea.

Safety note: Perchlorate salts of transition metal complexes with organic ligands are often explosive and should be handled with caution.

Preparation of $\mathbf{L}^{2}$. A toluene solution $(20 \mathrm{~mL})$ of $\mathrm{L}^{1}$ (Ref. 14) (2.0 g, $5.9 \mathrm{mmol}), 99 \%$ 1-bromo-2-methoxyethane (1.4 mL, $14.9 \mathrm{mmol})$, and $\mathrm{KOH}(2.0 \mathrm{~g}, 35 \mathrm{mmol})$ was refluxed for $48 \mathrm{~h}$. The reaction mixture was filtered at room temperature, and the filtrate was evaporated to leave semi solid. After the addition of acetonitrile $(20 \mathrm{~mL})$ to the residue, the mixture was stored at room temperature for $2 \mathrm{~h}$. The white solid formed was collected by filtration. The crude product was redissolved in methanol $(20 \mathrm{~mL})$ at room temperature and then filtered to remove any solid. The addition of $0.1 \mathrm{M} \mathrm{NaOH}$ aqueous solution $(20 \mathrm{~mL})$ produced a white solid. The product was collected by filtration, washed with water, and dried in air (Yield: 50\%). Anal. Calcd for $\mathrm{C}_{26} \mathrm{H}_{52} \mathrm{~N}_{4} \mathrm{O}_{2}$ : C, 68.98; H, 11.58; N, 12.38. Found: C, 68.60; H, 12.06; N, $12.31 \%$. GC-Mass $(\mathrm{m} / \mathrm{z}) 452\left(\mathrm{M}^{+}\right)$. IR (Nujol mull, $\left.\mathrm{cm}^{-1}\right) 3258\left(v_{\mathrm{N}-\mathrm{H}}\right) .{ }^{13} \mathrm{C}-\mathrm{NMR}\left(\mathrm{CDCl}_{3}\right)$ 20.6, 24.9, $25.4,25.5,26.0,26.5,47.0,49.5,54.5,58.9(\mathrm{~d}), 72.8\left(-\mathrm{CH}_{2}-\mathrm{O}-\right.$ $\left.\mathrm{CH}_{3}\right), 77.5\left(-\mathrm{CH}_{2}-\mathrm{O}-\mathrm{CH}_{3}\right) \mathrm{ppm}$.

Preparation of $\mathbf{L}^{3}$. A toluene solution $(20 \mathrm{~mL})$ of $\mathrm{L}^{1}(2.0 \mathrm{~g}$, $5.9 \mathrm{mmol}), 99 \%$ 1-bromo-2-methoxyethane (3.4 mL, 35.7 $\mathrm{mmol})$, and $\mathrm{KOH}(3.3 \mathrm{~g}, 60 \mathrm{mmol})$ was refluxed for $50 \mathrm{~h}$. The reaction mixture was filtered at room temperature, and the filtrate was evaporated. After the addition of methanol $(20 \mathrm{~mL})$ to the residue, the mixture was stored at room temperature to form a white solid. The product was collected by filtration and dissolved in minimum volume of hot methanol $\left(>50^{\circ} \mathrm{C}\right)$. The solution was evaporated slowly at room temperature until a 
white solid formed. The product was collected by filtration, washed with cold methanol, and dried in air (Yield: 30\%). Anal. Calcd for $\mathrm{C}_{32} \mathrm{H}_{64} \mathrm{~N}_{4} \mathrm{O}_{4}$ : C, 67.56; H, 11.34; N, 9.85. Found: C, 68.05; H, 12.57; N, $10.00 \%$. GC-Mass $(\mathrm{m} / \mathrm{z}) 568\left(\mathrm{M}^{+}\right)$. ${ }^{13} \mathrm{C}-\mathrm{NMR}\left(\mathrm{CDCl}_{3}\right)$ 18.9, 26.4, 26.7, 27.0, 31.2, 38.1, 45.6, 49.5, $50.5,59.0(d), 62.4,73.7\left(-\mathrm{CH}_{2}-\mathrm{O}-\mathrm{CH}_{3}\right), 74.0\left(-\mathrm{CH}_{2}-\mathrm{O}-\mathrm{CH}_{3}\right)$, $77.3\left(-\mathrm{CH}_{2}-\mathrm{O}-\mathrm{CH}_{3}\right), 77.5\left(-\mathrm{CH}_{2}-\mathrm{O}-\mathrm{CH}_{3}\right) \mathrm{ppm}$.

Preparation of $\left[\mathrm{CuL}^{2}\right]\left(\mathrm{ClO}_{4}\right)_{2}$. A methanol solution $(25 \mathrm{~mL})$ of $\mathrm{L}^{2}(2.0 \mathrm{~g}, 4.4 \mathrm{mmol})$ and $\mathrm{Cu}(\mathrm{OAc})_{2} \cdot \mathrm{H}_{2} \mathrm{O}(1.8 \mathrm{~g}, 8.8 \mathrm{mmol})$ was refluxed for $1 \mathrm{~h}$. After the addition of an excess amount of $\mathrm{NaClO}_{4}$, the mixture was stored in a refrigerator to precipitate a purple solid. The solid was collected by filtration, washed with methanol, and dried in air. The product was recrystallized from a hot acetonitrile-water (1:2) solution (Yield: 80\%). Anal. Calcd for $\mathrm{C}_{26} \mathrm{H}_{52} \mathrm{~N}_{4} \mathrm{CuCl}_{2} \mathrm{O}_{10}$ : C, 43.67; H, 7.33; N, 7.83. Found: C, 43.63; H, 7.21; N, $7.80 \%$. IR $\left(\mathrm{cm}^{-1}\right) 3250\left(v_{\mathrm{N}-\mathrm{H}}\right)$, $1100\left(v_{\mathrm{Cl}-\mathrm{O}}, \mathrm{ClO}_{4}^{-}\right)$. FAB mass $(\mathrm{m} / \mathrm{z}) 614.5\left\{\left[\mathrm{CuL}^{2}+\mathrm{ClO}_{4}\right]^{+}\right\}$, $515.5\left\{\left[\mathrm{CuL}^{2}-\mathrm{H}\right]^{+}\right\}$.

Preparation of $\left[\mathrm{NiL}^{2}\right]\left(\mathrm{ClO}_{4}\right)_{2}$. This compound was prepared by a method similar to that for $\left[\mathrm{CuL}^{2}\right]\left(\mathrm{ClO}_{4}\right)_{2}$, except that $\mathrm{Ni}$ $(\mathrm{OAc})_{2} \cdot 4 \mathrm{H}_{2} \mathrm{O}(2.2 \mathrm{~g}, 8.8 \mathrm{mmol})$ was reacted instead of $\mathrm{Cu}(\mathrm{OAc})_{2}$. $\mathrm{H}_{2} \mathrm{O}$. The orange compound was recrystallized twice from a hot acetonitrile-water (1:2) solution (Yield: 80\%). Anal. Calcd for $\mathrm{C}_{26} \mathrm{H}_{52} \mathrm{~N}_{4} \mathrm{CuCl}_{2} \mathrm{O}_{10}$ : C, 43.96; $\mathrm{H}, 7.38 ; \mathrm{N}, 7.89$. Found: C, 44.01; H, 7.53; N, $7.88 \%$. IR $\left(\mathrm{cm}^{-1}\right) 3115\left(v_{\mathrm{N}-\mathrm{H}}\right), 1100$ $\left(v_{\mathrm{Cl}-\mathrm{O}}, \mathrm{ClO}_{4}{ }^{-}\right)$.

Preparation of $\left[\mathbf{N i L}^{2}\right]\left(\mathbf{P F}_{6}\right)_{2}$. A warm acetonitrile $(c a .10 \mathrm{~mL})$ suspension of $\left[\mathrm{NiL}^{2}\right]\left(\mathrm{ClO}_{4}\right)_{2}(\mathrm{ca} .0 .4 \mathrm{~g})$ and $\mathrm{NH}_{4} \mathrm{PF}_{6}(1.5 \mathrm{~g})$ was stirred for $10 \mathrm{~min}$ and then filtered to remove any solid. After the addition of water $(20 \mathrm{~mL})$ to the filtrate, the mixture was evaporated to yield an orange solid. The product was collected by filtration, washed with water, and dried in air. Yield: $\sim 90 \%$. FAB mass $(m / z) 655.6\left\{\left[\mathrm{NiL}^{2}+\mathrm{PF}_{6}\right]^{+}\right\}, 509.5\left\{\left[\mathrm{NiL}^{2}\right.\right.$ $\left.-\mathrm{H}]^{+}\right\}$. IR $\left(\mathrm{cm}^{-1}\right) 3121\left(v_{\mathrm{N}-\mathrm{H}}\right), 850\left(v_{\mathrm{P}-\mathrm{F}}, \mathrm{PF}_{6}{ }^{-}\right) .{ }^{13} \mathrm{C}-\mathrm{NMR}$ $\left(\mathrm{CD}_{3} \mathrm{NO}_{2}\right): 19.4,26.9,27.4,35.3,49.7,53.9,55.6(d)$ 59.2, $62.9(d), 72.5\left(-\mathrm{CH}_{2}-\mathrm{O}-\mathrm{CH}_{3}\right), 78.4\left(-\mathrm{CH}_{2}-\mathrm{O}-\mathrm{CH}_{3}\right) \mathrm{ppm}$.

Preparation of $\left[\mathrm{Cu}\left(\mathrm{HL}^{3}\right)\right]\left(\mathrm{ClO}_{4}\right)_{3} \cdot \mathbf{2 H}_{2} \mathrm{O}$. A methanol solution $(25 \mathrm{~mL})$ of $\mathrm{L}^{2}(2.0 \mathrm{~g}, 3.5 \mathrm{mmol})$ and $\mathrm{Cu}(\mathrm{OAc})_{2} \cdot \mathrm{H}_{2} \mathrm{O}(1.4 \mathrm{~g}$, $7.1 \mathrm{mmol}$ ) was refluxed for $3 \mathrm{~h}$ and then cooled to room temperature. After the addition of an excess amount of $\mathrm{NaClO}_{4}$ and $2 \sim 3$ drops of $\mathrm{HClO}_{4}$, the solution was evaporated slowly at room temperature until a green precipitate formed. The solid was collected by filtration, washed with cold methanol, and dried in air. The product was recrystallized from a methanol-water $(1: 2)$ solution (Yield: $\sim 60 \%$ ). Anal. Calcd for $\mathrm{C}_{32} \mathrm{H}_{69} \mathrm{~N}_{4} \mathrm{CuCl}_{3} \mathrm{O}_{18}$ : C, 39.71; H, 7.19; N, 5.79. Found: C, 39.75; H, 7.81; N, 5.87\%. FAB mass $(m / z) 831.9\left\{\left[\mathrm{Cu}\left(\mathrm{HL}^{3}\right)+2 \mathrm{ClO}_{4}\right]^{+}\right\}, 730.9\{[\mathrm{Cu}$ $\left.\left.\left(\mathrm{L}^{3}\right)+\mathrm{ClO}_{4}\right]^{+}\right\}, 631.1\left\{\left[\mathrm{Cu}\left(\mathrm{L}^{3}\right)-\mathrm{H}\right]\right\}$. IR $\left(\mathrm{cm}^{-1}\right) 3500-3300$ $\left(v_{\mathrm{OH}}, b r\right), 1100\left(v_{\mathrm{Cl}-\mathrm{O}}, \mathrm{ClO}_{4}{ }^{-}\right)$.

Crystal structure determination. A purple crystal of $\left[\mathrm{CuL}^{2}\right]$ $\left(\mathrm{ClO}_{4}\right)_{2}$ was obtained from water-acetonitrile. Intensity data were collected on a Rigaku R-AXIS RAPID II-S diffractometer equipped with graphite monochromated Mo $\mathrm{K} \alpha(\lambda=$ $0.71073 \AA$ ) radiation source and imaging plate detector (460 $\mathrm{mm} \times 256 \mathrm{~mm}$ ). A total of 240 oscillation images were collected at $100 \mathrm{k}$ using widths of $3^{\circ}$ in $\omega$. The raw data were processed to give structure factors using the RAPID AUTO program. The structure was solved by direct method and refined by full matrix least squares against $\mathrm{F}^{2}$ for all data using SHELXL-97. ${ }^{15}$ All non-hydrogen atoms were anisotropically refined. All other hydrogens were included in the calculated position.

Crystal and refinement data: $\mathrm{C}_{26} \mathrm{H}_{52} \mathrm{~N}_{4} \mathrm{CuCl}_{2} \mathrm{O}_{10}, M=715.16$, monoclinic, $C 2 / c, a=17.331(1), b=11.401(1), c=17.471(1) \AA$, $\beta=116.333(1)^{\mathrm{o}}, V=3094.0(2) \AA^{3}, Z=4, D_{\text {calc }}=1.535 \mathrm{~g} \mathrm{~cm}^{-3}$, $\mu=9.40 \mathrm{~cm}^{-1}$, Goodness-of-fit on $F^{2}=1.075$, Final $R_{1}=0.0353$, $w R_{2}=0.0874(I>2 \sigma(I)), R_{1}=0.0433, w R_{2}=0.0907$ (all data).

\section{Results and Discussion}

Synthesis. The major product prepared from the reaction of $\mathrm{L}^{1}$ with 1-bromo-2-methoxyethane in a 1:2.5 molar ratio was $\mathrm{L}^{2}$ bearing two $\mathrm{N}-\mathrm{CH}_{2} \mathrm{CH}_{2} \mathrm{OCH}_{3}$ pendant arms. The fully $\mathrm{N}$-methoxyethylated macrocycle $\mathrm{L}^{3}$ was also prepared by the reaction of $\mathrm{L}^{1}$ with an excess 1-bromo-2-methoxyethane. The di- $N$-substituted macrocycle $\mathrm{L}^{2}$ readily dissolves in methanol, whereas $\mathrm{L}^{3}$ is nearly insoluble at room temperature. In contrast to the cases of $\mathrm{L}^{4}$ and $\mathrm{L}^{5}$ bearing $\mathrm{N}-\mathrm{CH}_{2} \mathrm{OCH}_{3}$ pendant $\operatorname{arm}(\mathrm{s}),{ }^{10,11}$ both $\mathrm{L}^{2}$ and $\mathrm{L}^{3}$ are extremely stable in the solid state and in various solvents. The mass, infrared, and ${ }^{13} \mathrm{C}-\mathrm{NMR}$ spectral data of $\mathrm{L}^{2}$ and $\mathrm{L}^{3}$ are listed in the Experimental section. The structure of $\mathrm{L}^{2}$ was confirmed by the crystal structure of its copper(II) complex (see below).

Both $\left[\mathrm{CuL}^{2}\right]^{2+}$ and $\left[\mathrm{NiL}^{2}\right]^{2+}$ were prepared readily by the reaction of $\mathrm{L}^{2}$ with the corresponding metal ions. The fully$N$-substituted macrocycle $\mathrm{L}^{3}$ reacts with $\mathrm{Cu}^{2+}$ ion to form $\left[\mathrm{Cu}\left(\mathrm{HL}^{3}\right)\right]^{3+}$ where one of the four tertiary nitrogen atoms is protonated. The formation of $\left[\mathrm{Cu}\left(\mathrm{HL}^{3}\right)\right]^{3+}$ in the present work is quite different from the trend that most 14-membered tetraaza macrocycles bearing four $N$-alkyl pendant arms, such as $\mathrm{L}^{7}$ bearing four $N$-propyl groups, form square-planar copper(II) complexes, in which the metal ion is coordinated by all of the four tertiary nitrogen atoms. ${ }^{16,17}$ This can be attributed to the coordination ability of the $N-\mathrm{CH}_{2} \mathrm{CH}_{2} \mathrm{OCH}_{3}$ groups in $\mathrm{L}^{3}$. All efforts to prepare nickel(II) complex of $\mathrm{L}^{3}$ under various experimental conditions were unsuccessful; the addition of $\mathrm{NaClO}_{4}$ to the reaction mixture produced the white salt $\mathrm{L}^{3} \cdot 2 \mathrm{HClO}_{4}$.

Crystal structure of $\left[\mathrm{CuL}^{2}\right]\left(\mathbf{C l O}_{4}\right)_{2}$. The ORTEP drawing (Fig. 1) of the cation $\left[\mathrm{CuL}^{2}\right]^{2+}$ shows that two methoxyethyl groups are attached to the less sterically hindered nitrogen atoms of the macrocyclic ligand. The macrocycle containing

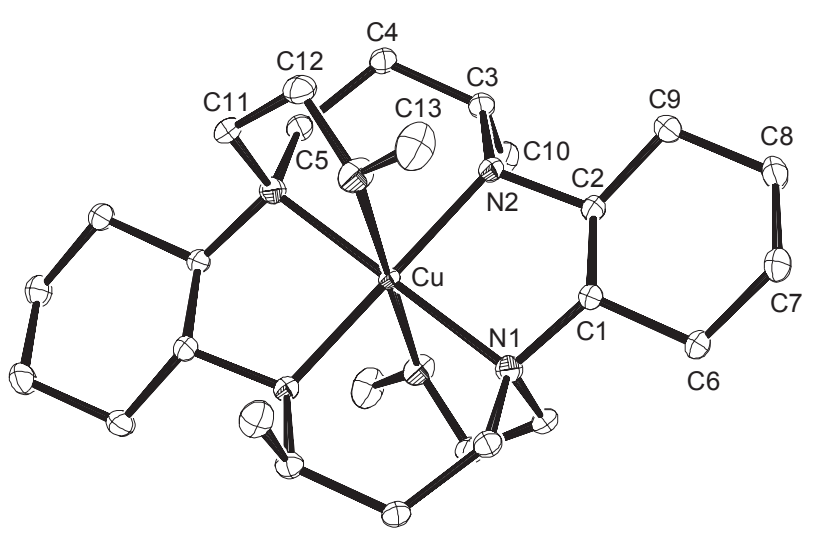

Figure 1. An ORTEP drawing of $\left[\mathrm{CuL}^{2}\right]^{2+}$ cation in $\left[\mathrm{CuL}^{2}\right]\left(\mathrm{ClO}_{4}\right)_{2}$. 
Table 1. Bond distances $(\AA)$ and angles $\left({ }^{\circ}\right)$ for $\left[\mathrm{CuL}^{2}\right]\left(\mathrm{ClO}_{4}\right)_{2}$

\begin{tabular}{lrlr}
\hline $\mathrm{Cu}-\mathrm{N}(1)$ & $2.067(2)$ & $\mathrm{Cu}-\mathrm{N}(2)$ & $2.043(2)$ \\
$\mathrm{Cu}-\mathrm{O}(1)$ & $2.595(2)$ & $\mathrm{C}(1)-\mathrm{N}(1)$ & $1.518(2)$ \\
$\mathrm{C}(2) \mathrm{N}(2)$ & $1.498(2)$ & $\mathrm{C}(12)-\mathrm{O}(1)$ & $1.422(3)$ \\
$\mathrm{C}(13)-\mathrm{O}(1)$ & $1.422(3)$ & & \\
$\mathrm{N}(1)-\mathrm{Cu}-\mathrm{N}(2)$ & $85.5(2)$ & $\mathrm{N}(1)-\mathrm{Cu}-\mathrm{N}\left(2^{\prime}\right)$ & $94.5(2)$ \\
$\mathrm{N}(1)-\mathrm{Cu}-\mathrm{N}\left(1^{\prime}\right)$ & $180.0(1)$ & $\mathrm{N}(2)-\mathrm{Cu}-\mathrm{N}\left(2^{\prime}\right)$ & $180.0(1)$ \\
$\mathrm{C}(11)-\mathrm{C}(12)-\mathrm{O}(1)$ & $108.5(2)$ & $\mathrm{C}(12)-\mathrm{O}(1)-\mathrm{C}(13)$ & $111.7(2)$ \\
$\mathrm{N}(1)-\mathrm{Cu}-\mathrm{O}(1)$ & $77.1(1)$ & $\mathrm{N}(2)-\mathrm{Cu}-\mathrm{O}(1)$ & $79.9(2)$ \\
\hline
\end{tabular}

two trans-1,2-diaminocyclohexane subunits adopts trans-III stereochemistry. The methoxyethyl group and the methyl group in each six-membered chelate ring are anti with respect to the plane.

The selected bond distances and angles of the complex are listed in Table 1. The Cu-N(1) (tertiary) distance (2.067 $\AA$ ) is longer than the $\mathrm{Cu}-\mathrm{N}(2)$ (secondary) distance (2.043(2) $\AA$ ). The in-plane $\mathrm{Cu}-\mathrm{N}$ distances are comparable with those of $\left[\mathrm{CuL}^{4}\right]$ $\left(\mathrm{ClO}_{4}\right)_{2} \cdot \mathrm{CH}_{3} \mathrm{CN}$ and other related macrocyclic complexes. ${ }^{10}$ The axial $\mathrm{Cu}-\mathrm{O}(1)$ distance $(2.595(2) \AA)$ indicates that the oxygen atoms of the pendant $\mathrm{N}-\mathrm{CH}_{2} \mathrm{CH}_{2} \mathrm{OCH}_{3}$ groups are coordinated to the metal ion relatively weakly. The $\mathrm{Cu}-\mathrm{O}(1)$ distance is much longer than the in-plane $\mathrm{Cu}-\mathrm{N}$ distances and is ca. $0.1 \AA$ longer than the $\mathrm{Cu}-\mathrm{O}$ (one of the two $\mathrm{N}-\mathrm{CH}_{2} \mathrm{OCH}_{3}$ groups) distance $(2.471(2) \AA)$ of $\left[\mathrm{CuL}^{4}\right]\left(\mathrm{ClO}_{4}\right)_{2} \cdot \mathrm{CH}_{3} \mathrm{CN} .{ }^{10}$ When the metal ion is directly coordinated by the $\mathrm{O}(1)$ atom, the complex has a trans-octahedral coordination polyhedron. The trans-N-Cu-N angles are $180^{\circ}$. The $\mathrm{N}(1)-\mathrm{Cu}-\mathrm{N}(2)$ angle $\left(85.5(2)^{\circ}\right)$ of the fivemembered chelate ring is smaller than the $\mathrm{N}(1)-\mathrm{Cu}-\mathrm{N}\left(2^{\prime}\right)$ angle $\left(94.5^{\circ}\right)$ of the six-membered chelate ring. The $\mathrm{C}(12)-\mathrm{O}(1)-$ $\mathrm{C}(13)$ angle $\left(111.7^{\circ}\right)$ is similar to the C-O-C angle $\left(112.8^{\circ}\right)$ involved in the coordinated $N-\mathrm{CH}_{2} \mathrm{OCH}_{3}$ group of $\left[\mathrm{CuL}^{4}\right]\left(\mathrm{ClO}_{4}\right)_{2}$. $\mathrm{CH}_{3} \mathrm{CN}{ }^{10}$

Properties of $\left[\mathrm{CuL}^{2}\right]\left(\mathrm{ClO}_{4}\right)_{2}$ and $\left[\mathrm{NiL}^{2}\right]\left(\mathrm{ClO}_{4}\right)_{2}$. Both $\left[\mathrm{CuL}^{2}\right]$ $\left(\mathrm{ClO}_{4}\right)_{2}$ and $\left[\mathrm{NiL}^{2}\right]\left(\mathrm{ClO}_{4}\right)_{2}$ dissolve in various polar organic solvents, such as nitromethane, acetonitrile and DMSO, but is nearly insoluble in water. They are relatively inert against decomposition even in concentrated acid solutions, in analogy with other related copper(II) and nickel(II) complexes of 14membered tetraaza macrocycles; ${ }^{9,10}$ the electronic absorption spectra of the complexes measured in $0.1 \mathrm{M} \mathrm{HClO}_{4}$ acetonitrilewater (1:1) solutions show that only less than $5 \%$ of the complexes are decomposed in $24 \mathrm{~h}$ at room temperature.

Infrared spectra of $\left[\mathrm{CuL}^{2}\right]\left(\mathrm{ClO}_{4}\right)_{2}$ and $\left[\mathrm{NiL}^{2}\right]\left(\mathrm{ClO}_{4}\right)_{2}$ show $v_{\mathrm{N}-\mathrm{H}}$ of the secondary amino groups at 3250 and $3115 \mathrm{~cm}^{-1}$, respectively. The values of molar conductance for the complexes measured in nitromethane $\left(130-140 \Omega^{-1} \mathrm{~mol}^{-1} \mathrm{~cm}^{2}\right)$ and acetonitrile $\left(220-240 \Omega^{-1} \mathrm{~mol}^{-1} \mathrm{~cm}^{2}\right)$ indicate that they are 1:2 electrolytes. ${ }^{13} \mathrm{C}$-NMR spectrum (see Experimental section) of the nickel(II) complex corresponds to the structure of the macrocycle. Molar magnetic susceptibility of $\left[\mathrm{NiL}^{2}\right]\left(\mathrm{ClO}_{4}\right)_{2}$ was found to be a negative value at room temperature, showing that the complex is a diamagnetic substance.

The electronic absorption spectra (Table 2) of $\left[\mathrm{CuL}^{2}\right]\left(\mathrm{ClO}_{4}\right)_{2}$ measured in Nujol mull and various solvents show a $d-d$ transition band at $510-520 \mathrm{~nm}$. The wavelengths are similar to
Table 2. Electronic absorption spectral data ${ }^{a}$

\begin{tabular}{lllll}
\hline Complex & $\lambda_{\max }, \mathrm{nm}\left(\varepsilon, \mathrm{M}^{-1} \mathrm{~cm}^{-1}\right)$ & & \\
\hline$\left[\mathrm{NiL}^{1}\right]\left(\mathrm{ClO}_{4}\right)_{2}{ }^{b}$ & $463(73)$ & & & \\
{$\left[\mathrm{NiL}^{2}\right]\left(\mathrm{ClO}_{4}\right)_{2}{ }^{f}$} & $488(82)$ & $490(73)^{c}$ & $494(81)^{d}$ & $495^{e}$ \\
{$\left[\mathrm{NiL}^{5}\right]\left(\mathrm{ClO}_{4}\right)_{2}{ }^{f}$} & $485(84)$ & $484(64)^{c}$ & $485(51)^{d}$ & \\
{$\left[\mathrm{NiL}^{6}\right]\left(\mathrm{ClO}_{4}\right)_{2}{ }^{g}$} & $520(6.8)^{c}$ & $335(16)^{c}$ & & \\
{$\left[\mathrm{NiL}^{8}\right]\left(\mathrm{ClO}_{4}\right)_{2}{ }^{h}$} & $490(117)$ & & & \\
{$\left[\mathrm{NiL}^{9}\right]\left(\mathrm{ClO}_{4}\right)_{2}{ }^{i}$} & $484(109)$ & $486(103)^{b}$ & & \\
{$\left[\mathrm{CuL}^{1}\right]\left(\mathrm{ClO}_{4}\right)_{2}{ }^{b}$} & $487(113)$ & & & \\
{$\left[\mathrm{CuL}^{2}\right]\left(\mathrm{ClO}_{4}\right)_{2}$} & $509(134)$ & $511(130)^{c}$ & $517(168)^{d}$ & $520^{e}$ \\
$\left.\left[\mathrm{Cu}^{e} \mathrm{HL}^{3}\right)\right]\left(\mathrm{ClO}_{4}\right)_{3} \cdot 2 \mathrm{H}_{2} \mathrm{O}$ & $715(120)$ & $670(110)$ & $675^{e}$ & \\
{$\left[\mathrm{CuL}^{6}\right]\left(\mathrm{ClO}_{4}\right)_{2}{ }^{{ }^{e}}$} & $522(98)$ & $523(98)^{c}$ & & \\
{$\left[\mathrm{CuL}^{7}\right]\left(\mathrm{ClO}_{4}\right)_{2}{ }^{j}$} & $476(440)$ & & \\
{$\left[\mathrm{CuL}^{8}\right]\left(\mathrm{ClO}_{4}\right)_{2}{ }^{h}$} & $490(189)$ & & & \\
\hline
\end{tabular}

${ }^{a}$ In nitromethane at $20{ }^{\circ} \mathrm{C}$ unless otherwise specified. ${ }^{b}$ Ref. $14 .{ }^{c}$ In acetonitrile. ${ }^{d}$ In DMF. ${ }^{e}$ In Nujol mull. ${ }^{{ }^{\prime}}$ Ref. $11 .{ }^{g}$ Ref. $9 .{ }^{h}$ Ref. $18 .{ }^{i}$ Ref. $19 .{ }^{j}$ Ref. 16.

those of $\left[\mathrm{CuL}^{6}\right]\left(\mathrm{ClO}_{4}\right)_{2}$ bearing two $\mathrm{N}-\mathrm{CH}_{2} \mathrm{CH}_{2} \mathrm{OH}$ pendant arms and are considerably longer than those of various squareplanar copper(II) complexes, such as $\left[\mathrm{CuL}^{1}\right]\left(\mathrm{ClO}_{4}\right)_{2}$ and $\left[\mathrm{CuL}^{8}\right]$ $\left(\mathrm{ClO}_{4}\right)_{2}{ }^{9,14,18}$ This corresponds to the crystallographic result that two $\mathrm{N}-\mathrm{CH}_{2} \mathrm{CH}_{2} \mathrm{OCH}_{3}$ groups are involved in coordination. The spectra of $\left[\mathrm{NiL}^{2}\right]\left(\mathrm{ClO}_{4}\right)_{2}$ measured in various solvents, such as nitromethane and acetonitrile, show a $d$ - $d$ transition band at $c a$. $490 \mathrm{~nm}\left(\varepsilon=73-82 \mathrm{M}^{-1} \mathrm{~cm}^{-1}\right)$. The spectra are comparable with those of other square-planar nickel(II) complexes with di- $N$-alkylated macrocyclic ligands, such as $\left[\mathrm{NiL}^{8}\right]\left(\mathrm{ClO}_{4}\right)_{2}$ and $\left[\mathrm{NiL}^{9}\right]\left(\mathrm{ClO}_{4}\right)_{2},{ }^{18,19}$ but are quite different from those of the octahedral complex $\left[\mathrm{CuL}^{6}\right]\left(\mathrm{ClO}_{4}\right)_{2}{ }^{9}$ This observation as well as the molar magnetic susceptibility supports the suggestion that the pendant $\mathrm{N}-\mathrm{CH}_{2} \mathrm{CH}_{2} \mathrm{OCH}_{3}$ groups of $\left[\mathrm{NiL}^{2}\right]^{2+}$ are not directly coordinated to the metal ion in the solid state and in various solvents, unlike those in $\left[\mathrm{CuL}^{2}\right]^{2+}$.

Spectra and properties of $\left[\mathrm{Cu}\left(\mathrm{HL}^{3}\right)\right]\left(\mathrm{ClO}_{4}\right)_{3} \cdot 2 \mathrm{H}_{2} \mathrm{O}$. The complex is extremely stable in the solid state and is relatively stable even in low $\mathrm{pH}$. Visible absorption spectra of the complex $(6.0 \times$ $10^{-4} \mathrm{M}$ ) measured in $0.2 \mathrm{M} \mathrm{HClO}_{4}$ water-acetonitrile (1:1) solution showed no apparent decomposition during $3 \mathrm{~h}$ at room temperature.

FAB mass spectrum (see Experimental section) of $\left[\mathrm{Cu}\left(\mathrm{HL}^{3}\right)\right]$ $\left(\mathrm{ClO}_{4}\right)_{3} \cdot 2 \mathrm{H}_{2} \mathrm{O}$ as well as the elemental analysis strongly indicates that one of the four tertiary amino groups of the macrocycle is protonated and is not involved in coordination; two or three oxygen atoms as well as the other three tertiary amino groups of the macrocycle may be involved in coordination. The electronic absorption spectra (Table 2) of the complex show a $d-d$ transition band at $670-715 \mathrm{~nm}$, which is $c a .200 \mathrm{~nm}$ longer than that for $\left[\mathrm{CuL}^{2}\right]\left(\mathrm{ClO}_{4}\right)_{2}$ or $\left[\mathrm{CuL}^{7}\right]\left(\mathrm{ClO}_{4}\right)_{2}$. The spectra strongly support the suggestion that $\left[\mathrm{Cu}\left(\mathrm{HL}^{3}\right)\right]\left(\mathrm{ClO}_{4}\right)_{3} \cdot 2 \mathrm{H}_{2} \mathrm{O}$ is a complex with a 5-coordination environment. ${ }^{20-23} \mathrm{It}$ has been widely observed that regular and distorted trigonal bipyramidal copper(II) complexes exhibit an absorption band at $>670 \mathrm{~nm}$, whereas square-pyramidal copper(II) complexes show an absorption band at considerably shorter wavelength. ${ }^{20-22}$ Therefore, the coordination geometry may be considered intermediate between TBP and SP in the solid state. Unfortunately, we 
were unable to isolate single crystals of the complex suitable for X-ray work. Therefore, the coordination geometry of the copper(II) complex is not thoroughly investigated.

\section{Summary}

This work shows that both $\mathrm{L}^{2}$ and $\mathrm{L}^{3}$ bearing two and four $\mathrm{N}-\left(\mathrm{CH}_{2}\right)_{2} \mathrm{OCH}_{3}$ groups, respectively, can be prepared selectively by the reaction of $\mathrm{L}^{1}$ with 1-bromo-2-methoxyethane. The di- $N$-substituted macrocycle $\mathrm{L}^{2}$ readily forms its copper(II) and nickel(II) complexes. The $\mathrm{N}-\left(\mathrm{CH}_{2}\right)_{2} \mathrm{OCH}_{3}$ groups in $\left[\mathrm{CuL}^{2}\right]^{2+}$ are coordinated to the metal ion, whereas those in $\left[\mathrm{NiL}^{2}\right]^{2+}$ are not involved in coordination. Interestingly, $\mathrm{L}^{3}$ reacts with $\mathrm{Cu}^{2+}$ ion to form $\left[\mathrm{Cu}\left(\mathrm{HL}^{3}\right)\right]^{3+}$, in which one tertiary amino group is not involved in coordination.

Supplementary Material. Crystallographic data of $\left[\mathrm{CuL}^{2}\right]$ $\left(\mathrm{ClO}_{4}\right)_{2}$ are available from the Cambridge Structural Database, CCDC reference number 771902 (http://www.ccdc.cam.ac.uk, fax: +44-1223-336-033, or e-mail: deposit@ccdc.cam.ac.uk).

Acknowledgments. This research was supported in part by Basic Science Research Program through the National Research Foundation of Korea (NRF) funded by the Ministry of Education, Science and Technology (No. 2010-0007251).

\section{References}

1. Viola-Villegas, N.; Doyle, R. P. Coord. Chem. Rev. 2009, 253, 1906.

2. Costamagna, J.; Ferraudi, G.; Matsuhiro, B.; Vampus-Vallette, M.; Canales, J.; Villagran, M.; Vargas, J.; Aguirre, M. J. Coord. Chem. Rev. 2000, 196, 125

3. Lukes, I.; Kotek, J.; Vojtisek, P.; Hermann, P. Coord. Chem. Rev.
2001, 216-217, 287.

4. Organo, V. G.; Filatov, A. S.; Quartararo, J. S.; Friedman, Z. M.; Rybak-Akimova, E. V. Inorg. Chem. 2009, 48, 8458.

5. Silversides, J. D.; Allan, C. C.; Archibald, S. J. Dalton Trans. 2007, 971.

6. Kang, S.-G.; Nam, K.; Jeong, J. H. Inorg. Chim. Acta 2009, 362, 1083.

7. Kang, S.-G.; Kim, H.; Kim, N.; Jeong, J. H. Bull. Korean Chem. Soc. 2009, 30, 3101.

8. Siegfried, L.; Comparone, A.; Neuburger, M.; Kaden, T. A. Dalton Trans. 2005, 30 and references cited therein.

9. Kang, S.-G.; Kim, M.-S.; Choi, J.-S.; Whang, D.; Kim, K. J. Chem. Soc., Dalton Trans. 1995, 363.

10. Kang, S.-G.; Kweon, J. K.; Lee, Y. H.; Kim, J.-S.; Lee, U. Bull. Korean Chem. Soc. 2007, 28, 489.

11. Kang, S.-G.; Kweon, J. K.; Jeong, G. R.; Lee, U. Bull. Korean Chem. Soc. 2008, 29, 1905.

12. Suh, M. P.; Choi, J.; Kang, S.-G.; Shin, W. Inorg. Chem. 1989, $28,1763$.

13. Suh, M. P.; Lee, J.; Han, M. Y.; Yoon, T. S. Inorg. Chem. 1997, 36,5651 .

14. Kang, S.-G.; Kweon, J. K.; Jung, S.-K. Bull. Korean Chem. Soc. 1991, 12, 483.

15. Sheldrick, G. M. SHELEXL-97, University of Goettingen, Goettingen, Germany, 1997.

16. Kang, S.-G.; Kim, M.-S.; Choi, J.-S. Cho, M. N. Polyhedron 1995 , 14, 781 .

17. Kang, S.-G.; Choi, J.-S.; Nam, K.; Chun, H; Kim, K. Inorg. Chim. Acta 2004, 357, 2783.

18. Kang, S.-G.; Ryu, K. Bull. Korean Chem. Soc. 2000, 21, 535.

19. Kang, S.-G.; Kim, M.-S.; Whang, D.; Kim, K. Inorg. Chim. Acta 1998, 279, 238.

20. Styka, M. C.; Smierciak, R. C.; Blinn, E. L.; DeSimone, R. E.; Passariello, J. V. Inorg. Chem. 1978, 17, 82 and references therein.

21. Duggan, M.; Ray, N.; Hathaway, B.; Tomlinson, G.; Brint, P.; Pelin, K. J. Chem. Soc., Dalton Trans. 1980, 1342.

22. Kang, S.-G.; Kim, N.; Jeong, J. Inorg. Chim. Acta 2008, 361, 349.

23. McLachlan, G. A.; Fallon, G. D.; Martin, R. L.; Spiccia, L. Inorg. Chem. 1995, 34, 254. 